Jurnal Bisnis dan Manajemen, Volume 20, No. 2, September 2019, p. 175-193

\title{
TECHNOLOGY FORESIGHT OF PATENT MANAGEMENT: AN OVERVIEW ON BIG DATA FOR REPOSITORY FIELDS
}

\author{
Tommy Hendrix \\ Indonesian Institute of Sciences, Indonesia
}

\begin{abstract}
The development of technology for entering the revolution industries 4.0 era nowadays becomes a hot issue in all industries. This condition is more interesting to discover in reducing budget expenditure, especially in the production process and obtaining raw materials. One of the tools that can be used is through technology foresight in patent management to see more information and predict the advanced technology which brings a competitive advantage in the digital era. Big data in fields of the repository is an urgent requirement, especially in collecting data from R \& D results. So, it will facilitate data retrieval within a specific time. This paper discusses how a user knows the development and predicts technology for market segmentation through a patent portfolio, licensing, status, competitor, innovation, and monitoring emerging market with a patent database registered on WIPO. The methodology used software Innography (Licensed). This paper aims to analyze patent database of big data for repository, related to the development of technology foresight products that have been produced, as well as to study the competitors' movement. The result shows that there are 1262 registered patents with seventeen patents and six organizations acting as assignees from 2004 until 2018. This paper is beneficial to the industry and stakeholders needing the impact of the implementation of the latest technology and the appropriate level of competition in the commercialization of big data for the repository as a digital system for information technology.
\end{abstract}

Keywords: big data for repository, overview, patent management, technology foresight

\section{MANAJEMEN PATEN MELALUI TEKNOLOGI PENELUSURAN: SUATU GAMBARAN BIG DATA PADA BIDANG REPOSITORI}

\begin{abstract}
ABSTRAK
Perkembangan teknologi menuju era revolusi indistri 4.0, saat ini menjadi pembicaraan khusus terutama disektor industri. Keadaan saat ini menjadi sangat menarik untuk di telusur guna untuk menurunkan tingkat pengeluaran terutama disektor produksi dan bahan baku. Salah satu perangkat yang dipergunakan adalah penelusuran teknologi dalam manajemen paten untuk mencari informasi dan memprediksi keunggulan teknologi yang dapat meningkatkan persaingan kompetitif di era digital. Bidang repository didalam big data merupakan salah satu kebutuhan yang penting dan dibutuhkan, terutama mengumpulkan data hasil penelitian dan pengembangan, serta memfasilitasi penarikan data pada waktu tertentu.Makalah ini membahas bagaimana pengguna mengetahui perkembangan dan memprediksi teknologi menuju segmentasi pasar melalui portofolio paten, lisensi, status, pesaing, monitoring dan inovasi perkembangan pasar dengan mempergunakan database paten yang terdaftar di WIPO. Methodologi yang dipergunakan adalah menggunakan software innograhpy (terdaftar) guna untuk melihat informasi yang berhubungan dengan big data di bidang repositori seperti pengguna potensial yang terdaftar pada kantor pendaftaran paten. Tujuan makalah ini adalah mendapatkan analisis paten database pada big data dibidang repositori terkait pengembangan penelusuran teknologi produk yang sudah diproduksi dan pergerakan dari pesaing. Hasil data yang diperoleh sebanyak 1262 paten terdaftar dengan data yang cocok sebanyak 17 paten dan 6 organisasi sebagai pengguna teknologi selama selang waktu 2004 sampai 2018. Makalah ini sangat menguntungkan bagi industri dan pengguna lainnya yang membutuhkan hasil penerapan dari teknologi terbaru dan tepat guna untuk berkompetisi didalam komersialisasi bidang repositori big data.
\end{abstract}

Kata-kata kunci: big data untuk repositori, gambaran umum, manajemen paten, penelusuran teknologi,

Korespondensi: Tommy Hendrix, ST., M.Si. Pusat Penelitian Kebijakan dan Manajemen IPTEK dan Inovasi, Lembaga Ilmu Pengetahuan Indonesia. Gedung PDDI Lt. 4, Jl Jend. Gatot Subroto 10 Jakarta 12710. Email: tommy.hendrix@gmail.com

Submitted: August 2019, Accepted: September 2019, Published: September 2019

ISSN: 1412 - 3681 (printed), ISSN: 2442 - 4617 (online), Website: http://journal.feb.unpad.ac.id/index.php/jbm 
Jurnal Bisnis dan Manajemen, Volume 20, No. 2, September 2019, p. 175-193

\section{INTRODUCTION}

Nowadays, the use of big data for the repository becomes essential in delivering datasets that can be stored and accessed easier and more flexible. In the revolution industry of 4.0., the roles of big data seem to give more room to deliver intensive movement in storage, especially in the repository when human energy can be replaced by machinery in the field of information technology. Industries continuously come up with new models that can use distributed architectures to process data more quickly and efficiently. A repository is a shared database of information about engineered artifacts (Bernstein, 1998). In other words, artifacts can be like software engineering that run system operations such as models and patterns. While data collection, compiled in a database, still has to manage the source of metadata for the growing part of the database, driven by many trends in information technology. These conditions have to expand with many possibilities for developing repositories fields, while business process reengineering moves faster in the digital era.

The need for information technology is still in the top position on market demand to seek much availability in benchmarking products that can be consumer requirements. Thus, the information in a patent analysis can capture opportunities or adopt the technology gaps, as well as utilising the technology can even develop into a better direction over the existing technology. From past experiments, it was shown that patent analysis can be a solution as a key tool to determine and analyze industry trends. It provides a way to envisage technology trajectories and to identify on-going developments of organizations (companies, government agencies, centers, and universities), so it is a crucial tool to support strategic planning in terms of R\&D as well as innovation (Hsieh, 2013).

In this research, patent mining is developed to determine trends in big data for repositories fields. Main countries' locations, organizations, inventors, and technology strength areas through International Patent Classifications (IPCs) were identified, as well as the last inventions of top players.

The purpose of this study is to offer valuable knowledge to decision-makers interested in knowing patent activity, including technological advances and key players of big data for repositories fields. This paper also focuses on technologies that can be utilised by users as well as through the implementation of the technology transfer of big data for repository, based on patents have been registered. This patent analysis using license Software Innography can be used to know the orientation of technological development in the market through licensing, patent portfolio, status, competition, innovation, and market monitoring derived from World International Patent Organization (WIPO) database.

The recommendation resulted from this research will fill out for policymakers in choosing alternative technologies that are appropriate market-oriented. With the use of patent documents, it is possible to know the growing trend of technology, players of technology, and even 
Jurnal Bisnis dan Manajemen, Volume 20, No. 2, September 2019, p. 175-193

competitors mastering specific technologies, especially in the field of big data for a repository.

More importantly, the results of this study can be incorporated for a broader strategic foresight analysis. Technology foresight is a process that systematically looks into the future to examine areas of research and emerging technologies (Grupp, 1999). Strategic foresight comprises the activities and processes that assist decision-makers in the task of defining the company's future course of action (Vecchiato, 2012). Strategic foresight provides business executives and government policymakers with interesting methods to envision the future. It also helps them to understand the implications of alternative technological or societal paths (Rohrbeck and Schwarz, 2013).

\section{LITERATURE REVIEW}

\section{Overview of Technology Development in Big Data for Repository Based on Patent Information}

The current issue regarding the movement technology is needed, especially by industries to enhance their branding and measure the obstacle in the process. Many types for measuring adaptability of technology can be used for instant foresight that applied in studies that try to anticipate and understand the potentialities, evolutions, characteristics, and effects of technological changes, particularly its invention, adoption, and usage. In industrial sectors need to change their traditional planning and be able to anticipate competitive environment movements. This condition needs to anticipate past with new strategy development in area technology development. On the other side, it was possible to anticipate the technological and scientific advances and participate in a way to influence the guidance of technological trajectories and from perspective emerges as an essential methodology.

The technology changes will bring many results, either a good or bad, depending on how we can follow the mainstream of the globalization era. In other words, it is essential to preserve many potential segments from innovation that lead to economic sustainability. Sequencing demands give us the chance to lift many appropriate technologies that appear from R \& D results. So, we can see implementation in the market sectors.

Foresight is essential for national technology planning, commercial strategies, and industrial knowledge. Industrial groups, government, and academia conduct studies for knowledge expansion (Andersen et al., 2014; Gallouj et al., 2015). Many countries engage in national foresight programs to assist them in cultural expansion or policy setting (Georghiou, Cassingena Harper, 2013; Keenan, Popper, 2008). Foresight is a set of systematic attempts in looking at the long-term future of science, technology, economy, and society. Besides, foresight allows us to identify emerging issues that are likely to generate higher social and economic benefits (Balbi, 2001).

Moreover, Popper (2008a) defines foresight as a process that involves intense iterative periods of open reflection, networking, consultation, and discussion, leading to joint refining of future visions and common ownership of strategies. Lin et 
Jurnal Bisnis dan Manajemen, Volume 20, No. 2, September 2019, p. 175-193

al. (2013), consider that foresight has evolved from being an explorative and tactical tool to become a strategic planning tool. This is not an instrument used to forecast or predict; instead, it is used to define alternative futures and create paths for potential developments.

Policy related to foresight's innovation define rationales in line with innovation policy paradigms, reflecting systems of innovation and evolutionary economics thinking and responding to aspects of market or system failure. The rationales and context dictate form, scale, and focus, and therefore, the results and impacts of foresight activity are varied, with a general move away from large scale programmes, to more modest, discrete, often embedded processes as part of other strategy and policy development initiatives. The differentiation policy interventions from one country or sector to another, nonetheless some fairly consistent messages have emerged into when foresight can be usefully applied to innovation policy.

Strategy implementation for foresight technology as a measurement $\mathrm{R} \& \mathrm{D}$ activities believe in the future will help much interest while interorganising connectivity for development growth to enhance boosting potential technology needs. The connectivity and the needs foresight technology analysis when implement in stakeholders (Lee, 2015) such as; first, by strengthening the relationship between technology foresight and innovation systems; second, by establishing a linkage between technology foresight and a technology roadmap in order to strengthen execution; third, by encouraging the participation of citizens in foresight activity.

Data mining encourages some progress that has been made with new data mining techniques (Huang et al., 2014), creating a smarter way to capture large amounts of data. It is instrumental to examine and understand the dynamics of the emerging field, mainly serving major data requirements. Figure 1 shows the milestone concept of foresight with data mining when it comes to the needs of the information technology database.

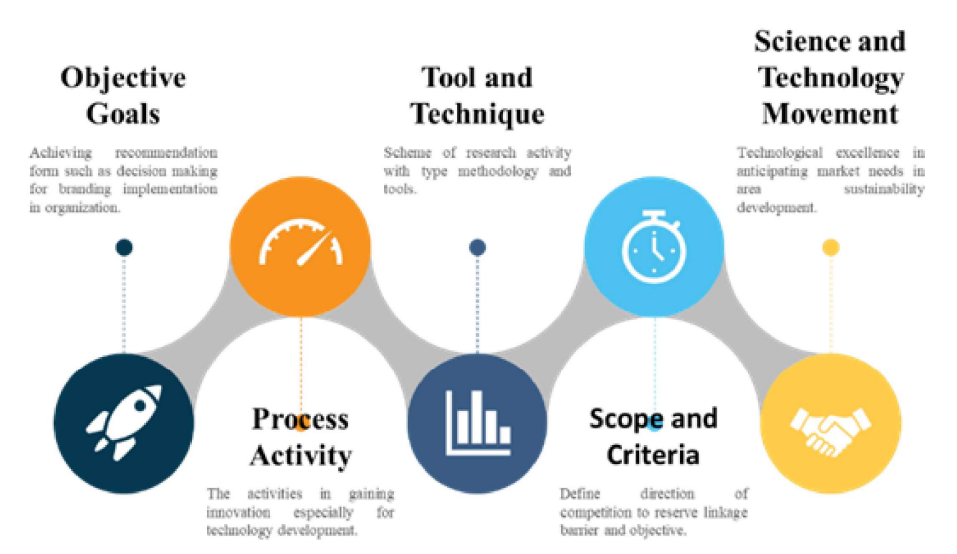

Figure 1. Foresight Technology Milestone for Mining Database

Source: Own Interpretation

Some examples in implementation using foresight technology have been the case in several sectors for objective analysis of 50 levels exercise in figure 2 regarding potential instrument for innovative public procurement, cluster policy, R \& D links and the development technology platform in form of critical benefits to enhance the effectiveness of indicator database. 
Jurnal Bisnis dan Manajemen, Volume 20, No. 2, September 2019, p. 175-193

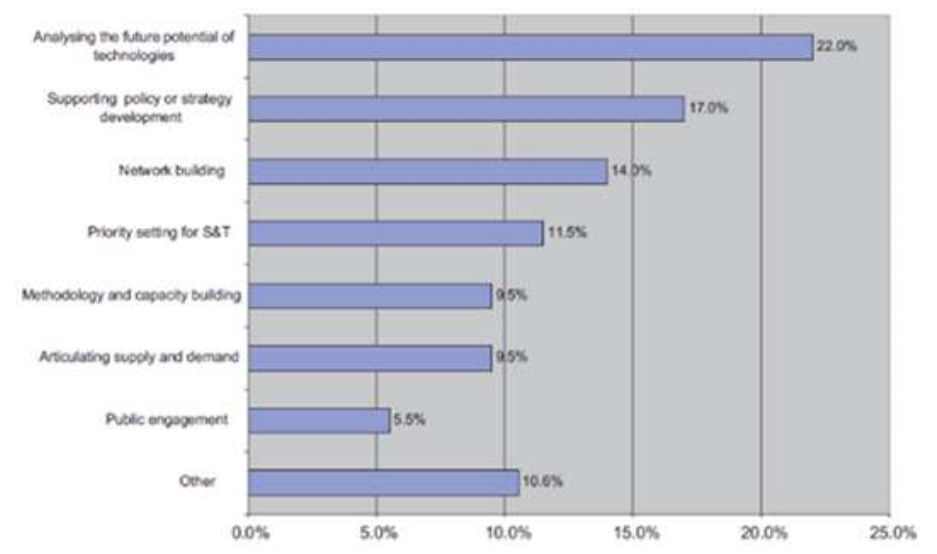

Figure 2. Analysis of Objectives of 50 Foresight Exercises

Source: Georghiou and Harper (2011)

The objective from figure 2 was to side by side see the priority trajectories fields in development technology sectors in the globalization era. These are needed to preserve many opportunities from innovation that lead to economic sustainability.

Technology foresight identifying future skills needs is becoming more and more acute in the context of the current dynamics of the global economy. Technology-driven sectors are an environment that is strongly associated with the most rapid change and, therefore uncertainty. Technological foresight is the term applied in studies that try to anticipate and understand the potentialities, evolutions, characteristics, and effects of technological changes, particularly its invention, adoption, and usage.

\section{Patent Information as Review Benchmarking Technology \\ In the modern era, many dynamic tools can be used} in measuring technology development. This opportunity appears while competition becomes the most dangerous in performing updating technology to compete in the global market. Many schemes have already used industrial analysis to measure comprehensive technology that has been used.

To ensure availability of technologies in a timely and affordable manner, some call for more flexibility in dealing with the relevant intellectual property rights (IPRs). For example, monitoring of technology provides dynamic analytics with high relevance information which can give us a result through analysis patent landscapes while creating an opinion on the process of mapping technology database. A patent is one of the seven types of IPR that has been officially implemented in the world through WIPO, loaded with information technology, economic, commercial and legal. Also, patent derivative product, i.e., one of the statistics fields containing a various database of IPRs in the world, can be used to monitor scientific activity, market trends, technology trend, dynamics of a competitor, and the innovation potential of the activities of a company. By using the right tools and good analytical skills, this information can be used as a strategy for the research and development of an organization (Ferianto and Hendrix, T., 2014).

Patent as a supporting program can be the source of R \& D results, especially in part of process technology transfer and licensing. It becomes IPRs that will bring up a somewhat tricky problem because countries, especially developing countries, will generally require IP owners to grant the license of transfer technology, enabling the guarantee for holders of such licenses to replicate the technology. It has spurred empowerment of $\mathrm{R}$ 
Jurnal Bisnis dan Manajemen, Volume 20, No. 2, September 2019, p. 175-193

$\& \mathrm{D}$ results that can be used by the license in the form of technology transfer, especially in using the patent as an intangible asset based on $\mathrm{R} \& \mathrm{D}$ activities (Hendrix, 2014). In comparison with other information sources, patents are often considered to be the best source for the timely recognition of technological changes (Rockhoff, 1991). It is presumably that technological fields with high relative patent growth rates will be more attractive in the future than those fields with low relative patent growth. Empirical studies show a positive and lagged relationship between patent growth and competitive changes in the market (Ernst, 1997).

Patents are the most accessible and reliable sources of information to assess technology (Hsieh, 2013). They are considered one of the most valuable output indicators of the technological innovation process (Hidalgo et al., 2009), (Rodríguez and Tello, 2012). The OECD has indicated that IPR plays a vital role in incentivizing innovation and the transmission of knowledge and economic performance (OECD, 2007). The relationship between IPR and economic performance is described as an inverted-U curve where IPR norms arrive at the highest point of rigidity from which the trade-off between the positive aspects of IPR for owners is eclipsed by the negative aspects (Cassandra and Sacha, 2015).

In this paper, the tool used to describe many advantages especially in providing actual worldwide database information related to the subject that wants to be found uses machine searching patent software. In this case, Innography software is used to determine useful potentials through strategy, research and development, patent analysis, and patent collaboration among users. The result from the patent document is referable to trace the development of the technology. Any technologies containing in the patent documents have a novelty and the advantages of technology than their predecessors. They can be the keys to see the differences in methodologies and systems that contain valuable information on patent application and specific confidentiality. The derivative searching result comprises patent per organization and market, IP Class, inventor, location and the other information matching with user requirement. Figure 3. shows cross-section in the usefulness of patent information for review technology database.

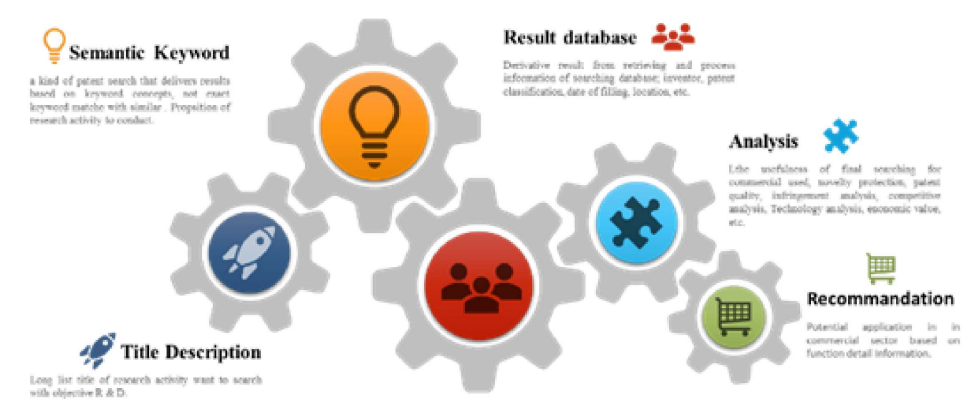

Figure 3. Scheme Process of Searching Patent Analysis Source: Own Interpretation

Inside this paper, patent information is shown with a right keyword to find document related to the development of prospecting utilization technology for derivative product, process and market orientation. This type of method is necessarily used to measure the level of development of the utilization technology and primarily the existing data through a patent database for searching possibilities of utilization that can be seen widely in the productive efforts. 
Jurnal Bisnis dan Manajemen, Volume 20, No. 2, September 2019, p. 175-193

So, the fulfillment of data can be clarified based on the existing uses.

\section{Big Data Requirement in Field of Repository}

The stored data, most commonly called big data, is very useful for the set of data services built to support the publication and discovery of data. It is also used to store and publish data from many domains. The production-ready data publication service offers a scalable repository where users can publish, preserve, and share even the largest research data. Data deposited is associated with a persistent identifier that can be uniquely referenced in publications. Users themselves manage access to published data, including options to share data publically or with specific groups of users. Published data can be described with a variety of standard, customized and domain-specific metadata, all of which are indexed in the data discovery service and may be searched by other users. It also serves metadata for management is a growing part of the database business, driven by many trends in information technology.

Global overview on concept big data nowadays came into dominant implementation especially through an explosion of data from the Internet, cloud, data centre, mobile, Internet of things, sensors, and domains that possess and process huge datasets. Volume, velocity, and variety are the main features of big data (Laney, 2001). These features make traditional computing models ineffective. A premise of tremendous value in the enormous datasets is the motive for big data exploration and exploitation. Big data has been identified with the potential to revolutionize many aspects of life (Philip, 2014); applications of big data in some domains have practically changed their practices (Huang, 2015). Data has penetrated each industry and all business functions; it is now considered a significant factor in production (James, 2011).

The lifecycle of a system engineered artifacts in big data, serve many objects with different types of de-fined, created, manipulated, and managed by a variety of tools that need to share data. The scheme of project managers used planning, tracking, financial analysis, and reporting tools to create and manage project plans, spreadsheets, and reports. The advantages of delivering storage function on big data for repository such as; (1) can find data independently through object fields, (2) avoiding inconsistency in share object fields, (3) connecting net-work on share data to another tools system, (4) control function in specific database fields, (5) updating database fields system, (6) also add in new query of database fields system. The forms of productoriented features of the data are volume, velocity, and variety. Big data imply contemporary technologies and architectures that have been designed to efficiently deduce benefit from huge and variety of datasets (Gantz and Reinsel, 2011). Another definition states big data involves huge volume, heterogeneous, localized control and finds intricate and dynamic correlations between data (Wu et al., 2014). Those advantages seem more useful to elaborate with integrating module 
Jurnal Bisnis dan Manajemen, Volume 20, No. 2, September 2019, p. 175-193

catching data transfer thus providing share semantic data properly.

Big data often used in a variety of domains, including data-driven science, telecommunications, social media, large-scale ecommerce, medical records and e-health, and so on. While exploring a database system can be linked and fused with other data, especially in mining experiences that address big data integration challenge is critical to realizing the promise of big data in these and other domains.

In this paper, repositories describe a brief function of storing datasets and provide access data including digitized data legacy, born-digital datasets and data catalogs. Data management in repositories is needed to extend research provenance documentation, with value connections from datasets to literature as well as intercitations among datasets and literature.

\section{Industrialization for Big Data in Market Oriented}

Revolution digital technology able to make easier people in generating all activities, also the addiction to using digital tools becomes more outstanding needed to receive any information regarding their needs. However, they do not know how difficult in building content of the tools to enhance many progressive features as a part of fulfilling the demand of users. In a big data analytics system, the vital foundation for an instant in fields of forecasting manufacturing, machine fleet, and proactive maintenance. Compared to big data in general, big industrial data has the potential to create value in different sections of the manufacturing business chain (Lee. J, 2015). Industrialization on big data analytics has attracted and captured much curiosity that expected in fields research and development interests from the stakeholder. Taking advantage of valuable industrial big data analytics will become basic competition for today's enterprises and will create new competitors who can attract employees that have the critical skills on big industrial data (Manyka et al., 2012).

The valuable technology of big data has divided into several categories of usefulness purposes, especially in market industrialization. The category has been described (Harvey, 2018), most big data solutions fall into one of the following categories: such as; 1. Business intelligence (BI), 2. Data mining, 3. Data integration, 4. Data management, 5. Open-source technologies, 6. Data lakes, 7. NoSQL databases, 8. Predictive analytics, 9. Prescriptive analytics, 10. In-memory databases, 11. Artificial intelligence and machine learning, 12. Data science platforms. It means, it is generative in the application used and performance of big data dominant in market acceptance as shown in Figure 4. That figure shows constrain each year development in the market industry regarding leading industrial based on their share of the global big data and analytics market in 2019 with the total market forecast to grow to 189.1 billion U.S. dollars in revenue in that year. 
Jurnal Bisnis dan Manajemen, Volume 20, No. 2, September 2019, p. 175-193

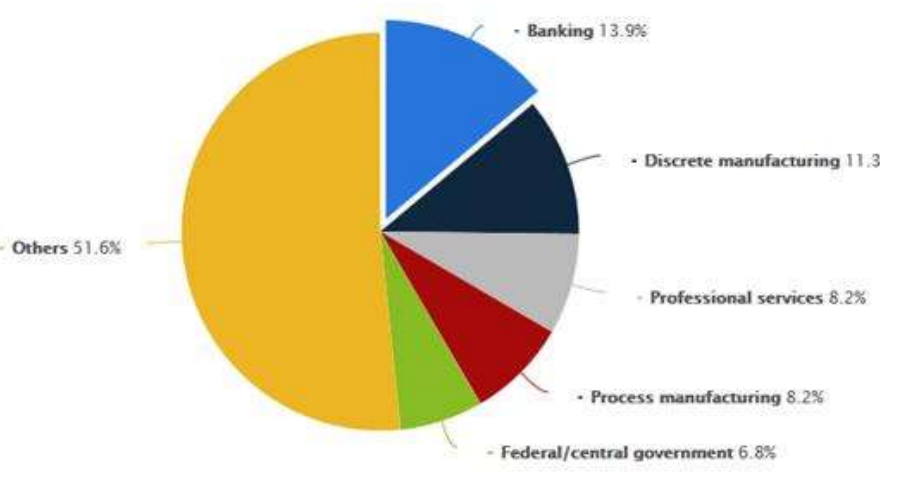

Figure 4. Share of Big Data and Business Analytics

Revenues Worldwide in 2019 (by industry) Source: statista.com (2019)

For industrial used forecast of big data market size, based on revenue, from 2011 to 2027 (in billion U.S. dollars) grow to 103 billion U.S. dollars by 2027 with a share of $45 \%$. As in figure 5.

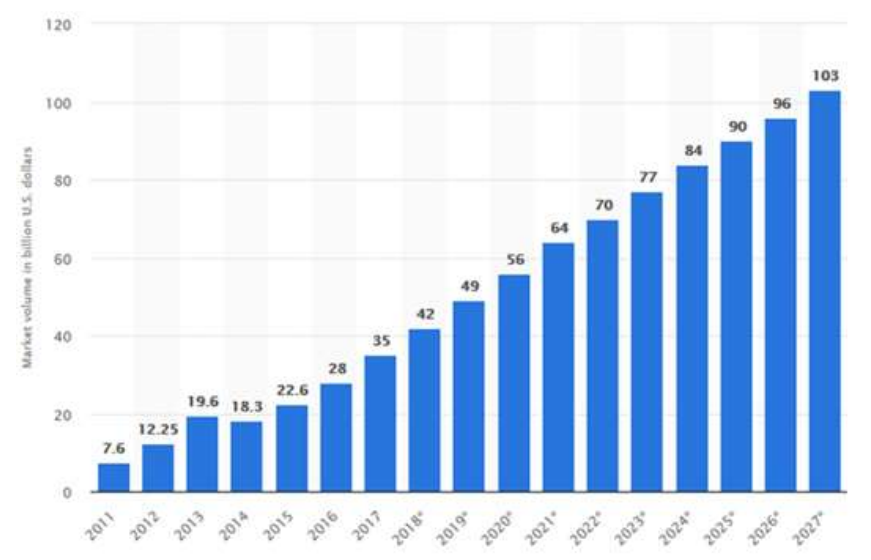

Figure 5 Forecast of Big Data market size, based on Revenue

Source: https://www.statista.com, Access June 28, 2019

From Figure 4 and 5, can define the outline result on the business prospect on big data requirement in industrial application and prediction total revenue yearly from 2011 until 2027 show how digital system on big data has the potential and prospective market capture becomes daily used in technology implementation especially in repository fields.

\section{METHODS}

This research paper uses qualitative research methodology, with an approach to studying literature patent utilization through R \& D foresight analysis of documents database from data mining and information. This study focuses on seeking the answers to the problems the study mainly on prospecting utilization of big data for the repository to enhance the development of market requirements. Data mining is one of the method or processes for extracting hidden patterns from a collection of certain data that emphasize data mining is the most important stages that transform data into patent information (Yanhong and Runhua, 2013). Data mining and in-formation are done with three approaches, namely:

\section{Literature Study}

Browsing information related to the topics and issues from various sources, such as books, journals, articles or papers of other scholars;

\section{Patent Benchmark}

Analysis of patent database through the document on technology foresight on big data for the repository, using software Innography which is sourced in the WIPO field.

\section{Interviews and Focused Discussion}

The interview is intended to keep up information on a research topic of experts associated with the object of research through a discussion. The discussion will be focused on obtaining information about big data for repository issues, a research study that has been and will be done 
Jurnal Bisnis dan Manajemen, Volume 20, No. 2, September 2019, p. 175-193

to overcome these problems. The second stage is the extraction of the data and information obtained from each approach. The last stage is to conduct the final analysis of the data and information analysis results obtained from the three approaches mentioned above.

The purpose of this study is to seek some information related to research topics through the international patent database that connected to the results of research and development of prospecting utilization big data for repository with technology foresight. The other target of searching and data analysis is to find the potential market portfolio and user that already apply for commercial interest and also to know the trends of technology and current research in progress. This paper is expected to become the input for potential users of technology and useful source of information in the development of science and technology, as well as the nature of the modification process is implementation and reverse engineering of technological information sourced from the patent.

\section{RESULTS AND DISCUSSION}

The comprehensive discussion regarding how the searching strategy has many purposes, especially in-process activities, involves the planned methodology and use of many different factors and tools. The consideration of using a methodology and some critical factors to be taken as a part of the search strategy are discussed.

Transfer of technology process is an effort and part of implementation onward using application for supporting the development of big data for repository with patent analysis. It gives us information in collecting data that can be used as benchmarking technology through foresight measurement. Foresight methods, using applications of data mining, exist for patent and publications analysis and show the roadmap of technology database.

Based on the result searching, it was indicated that a large number of data has been exploited on the basis of overview utilization of big data for repository using Innography software. The keyword used is "big data and repository" and we found about 1262 patents, registered in WIPO fields. We then selected only 17 patents that inline with the subject of big data for the repository. The subscribe form all that patent from the only search by title subject, and range of 15 years publication date (May 20, 2004, until May 20, 2018). The major authorities are US, GB, DE, KR, NL, and IN, including kind of document from Application and Granted file as well as pie chart, bubble, and table. The data requirements are mentioned below.

\section{Organization (Current Assignee)}

From searching organization, was the 1st user patent that receives the ownership on legal IP (current assignee). It means technology was used by the user for business development through implemented for production or concept of development in industries until now and concern in the area of commercialized under management organization. The results find from 17 Patents, only 
Jurnal Bisnis dan Manajemen, Volume 20, No. 2, September 2019, p. 175-193

6 Organizations have been used with bubble market such as;

1. International Business Machine Corporation (IBM), is a technology company. The Company operates through five segments: Cognitive Solutions, Global Business Services (GBS), Technology Services \& Cloud Platforms, Systems and Global Financing, with current assignee 8 patent (47.1\%), total revenue \$79.591.000.000.- All U.S. Patent Litigation 371. IBM has a resume portfolio in business activity in 10 years show in figure 6 ;

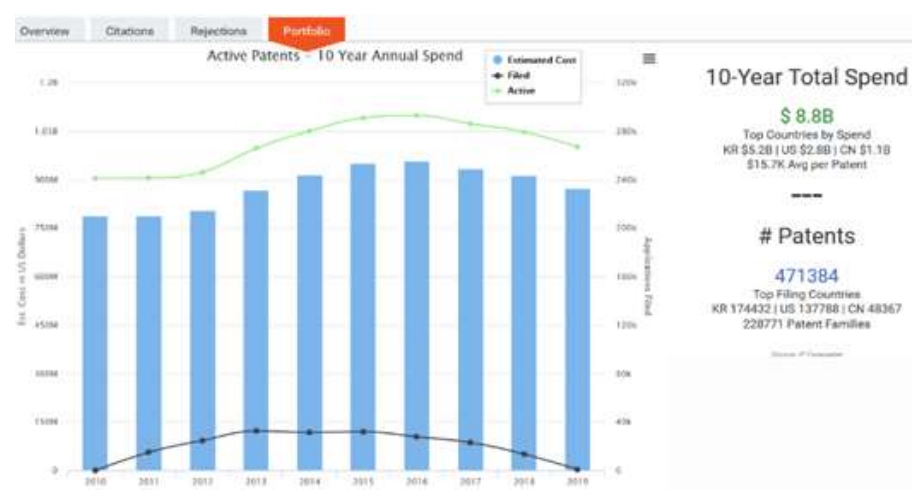

Figure 6. IBM Corp Spending Portfolio in 10 years Source: Innography (Processed)

2. Red Hat Inc., is an American multinational software company providing open-source software products to the enterprise community, with current assignee 4 patent $(23.5 \%)$, total revenue \$5.920.461.000.- All U.S. Patent Litigation 2. Red Hat Inc. has a resume portfolio in business activity in 10 years show in figure 7;

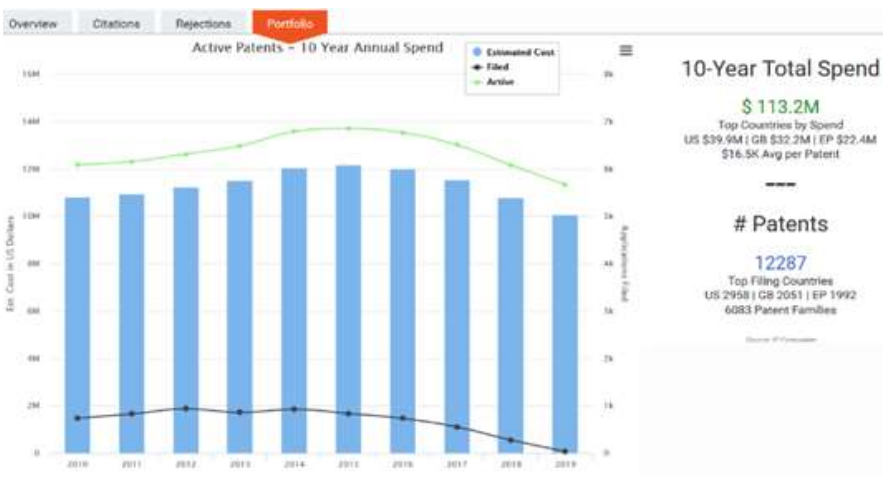

Figure 7 Red Hat Inc. Spending Portfolio in 10 years Source: Innography (Processed)

3. Samsung Electronics Co. Ltd., is a South Korean multinational electronics company, with current assignee 2 patent $(11.8 \%)$, total revenue \$224.821.584.504.- All U.S. Patent Litigation 1236. Samsung Electronics Co. Ltd. has a resume portfolio in business activity in 10 years show in figure 8;

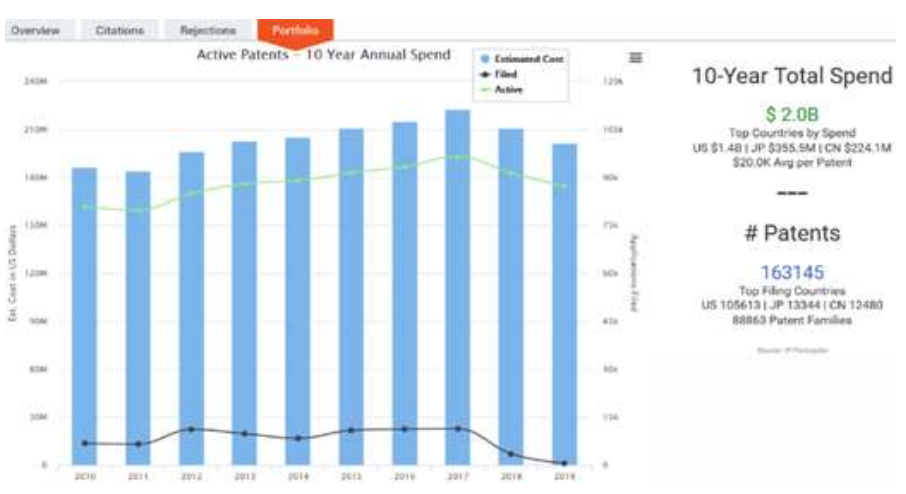

Figure 8. Samsung Electronics Co. Ltd. Spending Portfolio in 10 years

Source: Innography (Processed)

4. General Electric Company (GE), is an American multinational conglomerate incorporated operates through the following segments: aviation, healthcare, power, renewable energy, digital industry, additive manufacturing, venture capital and finance, lighting, and oil and gas, with current assignee 1 patent $(5.9 \%)$, total revenue $\$$ 121.615.000.000.- All U.S. Patent Litigation 513. General Electric Company (GE) have a 
Jurnal Bisnis dan Manajemen, Volume 20, No. 2, September 2019, p. 175-193

resume portfolio in business activity in 10 years show in figure 9;

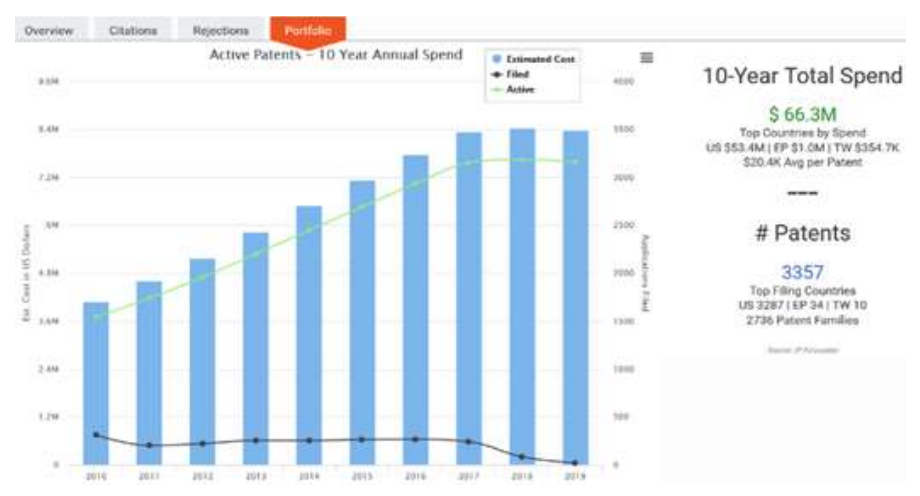

Figure 9. General Electric Company Spending Portfolio in 10 Years

Source: Innography (Processed)

5. Posco is the first integrated steel mill in Korea and conducting various global businesses, with current assignee 1 patent (5.9\%), total revenue \$ 59.290.720.000.- All U.S. Patent Litigation 9. Posco has resume portfolio in business activity in 10 years show in figure 10 ;

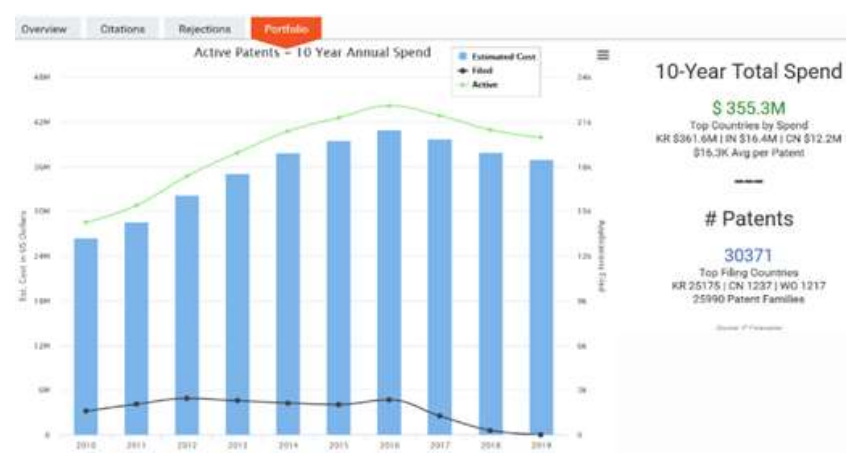

Figure 10. Posco Spending Portfolio in 10 Years Source: Innography (Processed)

6. Tata Sons Ltd. is an Indian multinational conglomerate holding company and the principal investment holding company and promoter of Tata companies, with current assignee 1 patent $(5.9 \%)$, total revenue $\$$ 28.800.000.000.- All U.S. Patent Litigation 16. Tata Sons Ltd. have resume portfolio in business activity in 10 years show in figure 11;

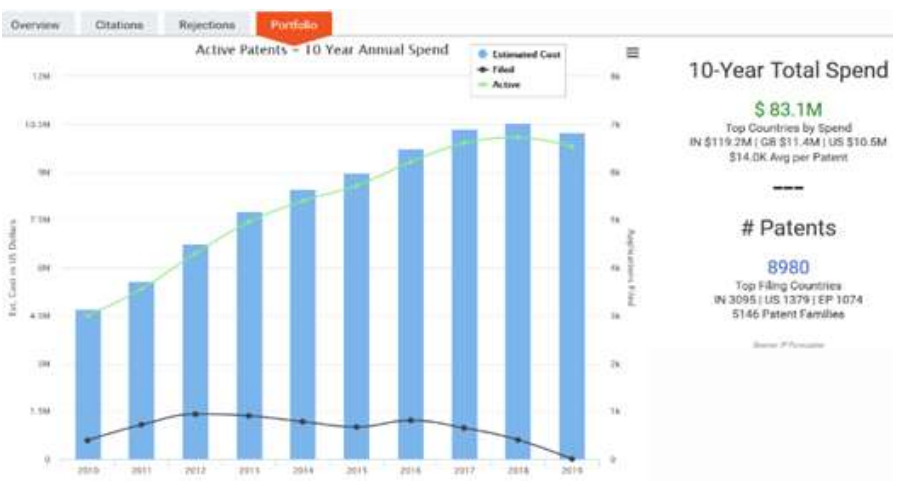

Figure 11. Tata Sons Ltd. Spending Portfolio in 10 Years Source: Innography (Processed)

From the description, we can trace current assignees came from America, Korea, and India with potential earning revenue from patent utilization and enforces the right to hold in frame of patent litigation from the market using big data for a repository. Figure 12 shows the organization for bubble market big data for the repository.

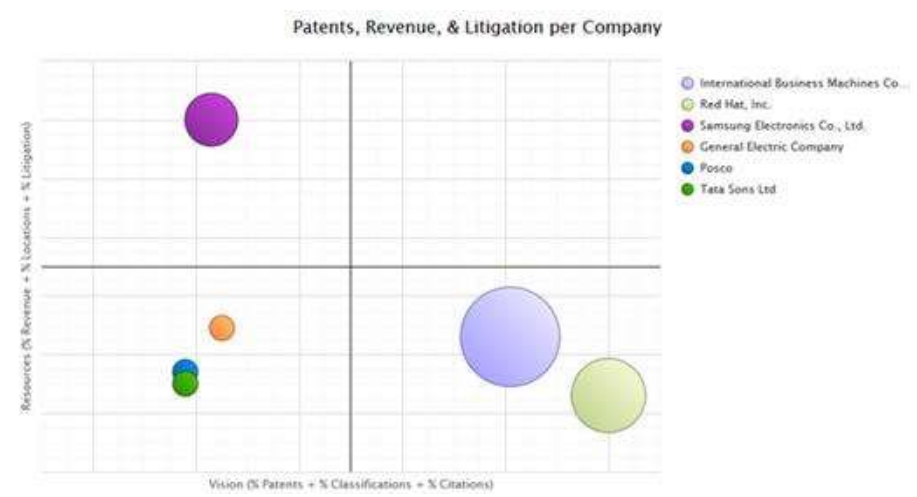

Figure 12. Organization for Bubble Market Big Data for Repository

Source: Software Total Patent (2019), processed

\section{Inventor (Patentee)}

A person who holds a certificate of a granted patent that concern in doing $\mathrm{R} \& \mathrm{D}$ have high value to boost up science and technology development and also who made an inventive contribution to the invention as defined by the claims of the patent application). The list if inventor who especially granted patent in field of big data for repository 
Jurnal Bisnis dan Manajemen, Volume 20, No. 2, September 2019, p. 175-193

show in top 20 Inventors of 32 Total and explaned in top 10 such as; Albert Maier with 8 patent $(15.5 \%)$ work as Senior Technical Staff Member in IBM's Analytics development organization; Yannick Saillet with 8 patent (15.5\%) work as software architect at IBM; Norman H Margolus with 4 patent (7.8\%) work as Research Affili-ate at the MIT Computer Science and Artificial Intelligence Laboratory; Harald Clyde Smith with 4 patent $(7.8 \%)$ work as software architect at IBM; Thomas F JR Knight with 3 patent (5.9\%) work as an synthetic biologist and computer engineer at the MIT Computer Science and Artificial Intelligence Laboratory; Harald Smith with 3 patent (5.9\%) work as software architect at IBM; Daniel C Wolfsohn with 3 patent (5.9\%) work as CTO \& Dir Data, Ana-lytics, IoT at IBM; Jared J Floyd with 2 patent $(3.9 \%)$ work as finance industry specialist at IBM; Charles Daniel Wolfson with 2 patent (3.9\%) work as CTO \& Dir Data, Analytics, IoT at IBM; Brahmannanda Sapkota 2 patent (3.9\%) work as software engineer Big Data R\&D Group, Samsung.
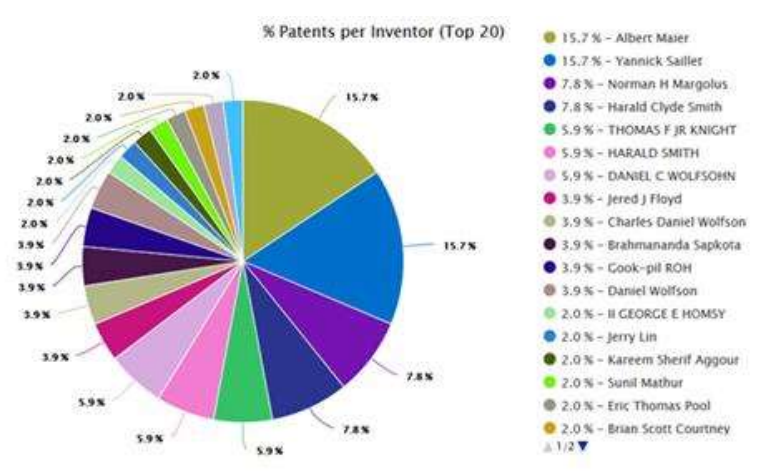

Figure 13. Top 20 Inventor in Big data for Repository Source: Innography (Processed)

\section{Location}

The information also consumed about the country where the patent was submitted and as patent authority were place and the country in which the patent registered show how many numbers that record-ed in WIPO database in the field of big data for the repository. Also commonly used and implemented to give value to production and market especially in the United State, Great Britain, Germany, Korea, Nederland and India with result 17 Patents, 6 Countries. The list of the country location showed in figure 14 shows in top 6 such as;
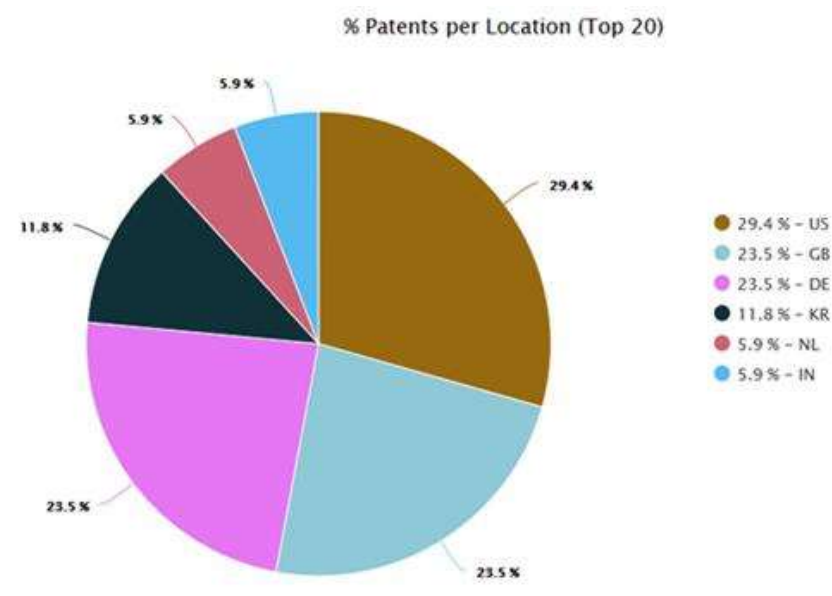

Figure 14. Patent Result by Location in Big Data for Repository Source: Innography (Processed)

\section{IP Class}

The World Intellectual Property Organization (2015) defines IPC as a "hierarchical system of language independent symbols for the classification of patents and utility models according to the different areas of technology to which they pertain". International Patent Classification (IPC), was a classification symbol for independent patent and utility model in areas of technology. Simplified data gathering process by using the first four digits of the IPC code in the patent analysis used as a proxy for examining the 
Jurnal Bisnis dan Manajemen, Volume 20, No. 2, September 2019, p. 175-193

technology scope (Gao et al., 2013). The field technology that refers to big data for repository patent with IPC intended to know hierarchical symbol that mostly uses in technology process and the result find;

G06F17/00 (G: Physics, G06: Computing; Calculat-ing; Counting, G06F: Electric Digital Data Processing (computer systems based on specific computational models G06N), G06F17/00: Digital computing or data processing equipment or methods, specially adapted for specific functions (information re-trieval, database structures or file system structures therefor G06F16/00) with 11 patent (64.7\%) IPC, G06F7/00 (G: Physics, G06: Computing; Calculating; Counting, G06F: Electric Digital Data Processing (computer systems based on specific computational models G06N), G06F7/00: Methods or ar-rangements for processing data by operating upon the order or content of the data handled (logic circuits H03K19/00) with 2 (11.8\%) IPC, G06F9/00 (G: Physics, G06: Computing; Calculating; Counting, G06F: Electric Digital Data Processing (computer systems based on specific computational mod-els G06N), G06F9/00: Arrangements for program control, e.g. control units (program control for pe-ripheral devices G06F13/10) with 2 (11.8\%) IPC, G06F21/00 (G: Physics, G06: Computing; Calculating; Counting, G06F: Electric Digital Data Processing (computer systems based on specific computational models G06N), G06F21/00: Security arrangements for protecting computers, components thereof, programs or data against unauthorised activity with
$1(5.9 \%)$ IPC, Unknown IPC that show per-sonal applied for patents in big data for repository fields. with $1(5.9 \%)$ IPC. Figure 15. Show the results 17 Patents, 5 IPC Groups from top 20 it's mean the scope of IPC for big data for repository still in the area of Physics and electric digital data processing.

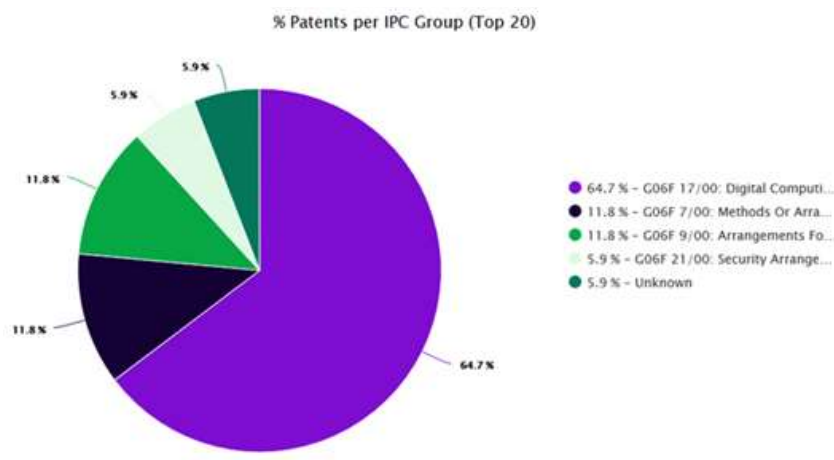

Figure 15 Top 6 IP Class in Big Data for Repository Source: Innography (Processed)

\section{Patent Strength (Bar) and Factor (Radar)}

In measuring competitiveness patent analyzing have to see dominant source especially for industrial applications. This potential information must show the strength and factors that are can influent the independencies of a patent application. For the company, this consumes product average of quality and activity to represent competitiveness technologies positions. On this side, innovation of technology must reflect a business strategy to compete with other technology users. Figure 16. Show the patent strength decile, results from 17 Patents, Top 10 Patent Strength Deciles will fluctuate with technical advances since it was issued, market demand trends for products using the patented technology, and the latest court rulings on interpreting patent law. In the form of decile means patents number can incorporate different 
Jurnal Bisnis dan Manajemen, Volume 20, No. 2, September 2019, p. 175-193

factors, both positive and negative, including the grant status, citation frequency, age, breadth, and examiner comments or office actions.

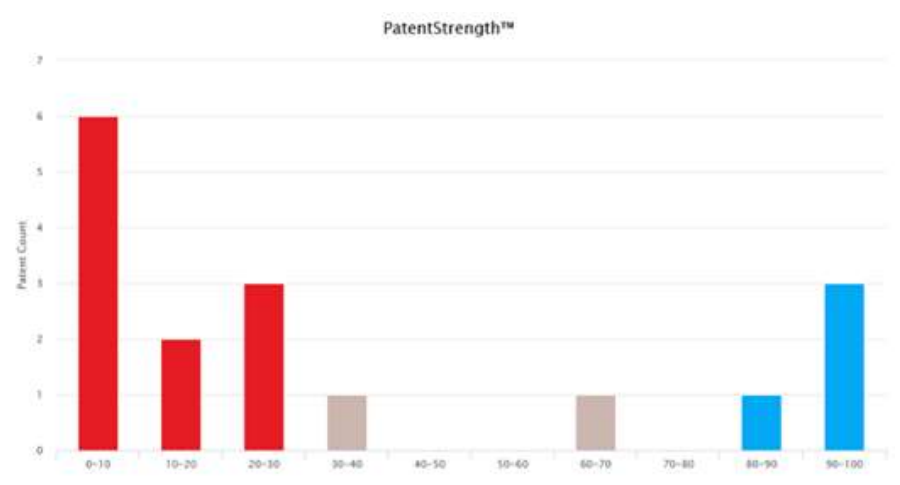

Figure 16. Patent Strength Decile in Big Data for Repository

Source: Innography (Processed)

From data above can be measure that strength capacity top 10 patent with data in red bar indicate very weak range $0-30$ with 11 patent, brown bar indicated intermediate-range $30-70$ with 2 patent and blue bar indicate strong range 70 - 100 with 4 patent its mean industrial applicable for big data for repository show business unit and strategic opportunity in the effort of developing derivative product diversification that is ready to market. A patentability technology for industrial used through reviews prior art to come to an opinion on the likelihood that claims in a patent application or invention disclosure will issue as a patent and research invested in the analysis versus the uncertainty in the assessment.

Strength factors (Radar) rely on how novel, unobvious and uniqueness solely upon modification of the prior product that is in crowded art on your invention, and also indicated the movement of patents influenced by an average of the patent claim (indisputably the most important part of a patent specification and defines the boundary of the patent by the invention and therefore what is sought to be protected).

Figure 17. shows how strength factors (radar) in big data for repository comply with challenges such as litigation, industries, claim, live, inventor cites, fwd cites related dimension of interaction about survivability intelligence with meaning covered patentability when meeting lawsuits.

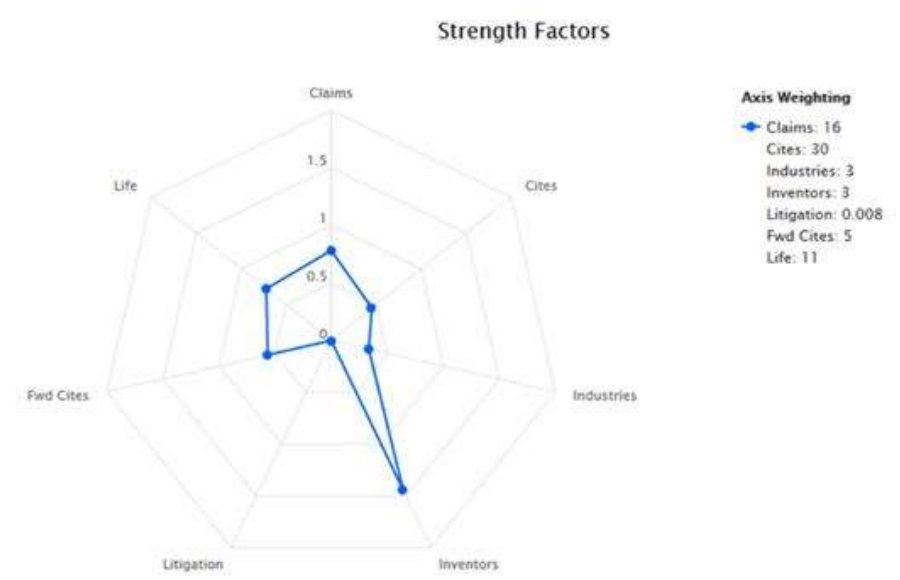

Figure 17. Strength Factors (Radar) in Big Data for Repository Source: Innography (Processed)

From Figure 17, we can see the description for recent opportunities on maturity patentability when it comes to stakeholder interest. The dimension of factors can be outlined such as;

1. Patent litigation is the act of law when someone who owns the patent for a particular invention enforces their right by using another for manufacturing or selling the invention without permission. Data interaction with average number 0 from axis weighting 0.008 means patent litigation have a high impact on protecting patents from infringement or violation of the law. 
Jurnal Bisnis dan Manajemen, Volume 20, No. 2, September 2019, p. 175-193

2. Patent Industries mean the implementation of countries' patent rights fall under civil law, and the patent holder needs to sue someone infringing the patent. Data interaction with average number 0.335067 from axis weighting 3 means patent industries have a low impact from industry application.

3. Patent Claim means to define the scope of what claimed as the invention that limitation of coverage of patent protection afforded under the patent. Data interaction with average number 0.782311 from axis weighting 16 mean patent claim have low limits of precisely what the patent does, and does not, cover.

4. Patent Life mean is the maximum period during which it can maintain in force from the filing date of the patent application or the date of grant of the patent. Data interaction with average number 0.721807 from axis weighting 11 means that patent life has a low impact from period protecting on filling until granted.

5. Patent Inventor means an inventor is a person, or persons in patent law, who contribute to the claims of a patentable invention. Data interaction with average number 1.441094 from axis weighting 3 mean patent inventor has a low position on productive producing patents each year.

6. Cites mean A patent citation is a document cited by an applicant, third party, or a patent office examiner because its content relates to a patent application. Data interaction with average number 0.452815 from axis weighting 30 mean patent cites have very low on citation each year and possible to target the acquisition of active patents, which results in the enhancement of R\&D output and, consequently, much improved or new products.

7. Fwd Cites means the applicant and the patent examiner must find and cite documents that may anticipate the claimed invention or might be similar to the claimed invention and limit the scope of the patent protection, or which generally reveal the state of the art of the technology. Data interaction with average number 0.566022 from axis weighting 5 mean fwd cites have a low impact on anticipating claim invention or similar invention from revealing state of the art.

\section{CONCLUSION}

Technology foresight implementation strategy can be conducted in the following manner; first, by strengthening the relationship between technology foresight and innovation systems; second, by making a linkage between technology foresight and technology roadmap for strengthening execution; and third, by encouraging the participation of citizens in foresight activity. Through technology foresight and intelligence activities, nations and organizations can adapt to new technology environments and sustain their competitiveness. Innovation in nations and organizations is crucial; however, innovation without foresight is like a ship without a compass.

Big data for the repository, nowadays becomes the needs in every field. Digital era in 
Jurnal Bisnis dan Manajemen, Volume 20, No. 2, September 2019, p. 175-193

development for data storage for industrial applications. R \& D in industry can be benefited by a more intense study of database research and development. However, a specific use occurs in general versions and configurations. Besides, it happens in the interoperability and heterogeneous repositories, repository managers, comparisons of commercial products, and case studies of using repositories in different tool domains.

Patent maturity informs the needs of big data for repository, and it still has a high value in the growing market. It shows how potential development in which the current assignee is dominant for its successful business. Low litigation has shown a good track in the implementation, including a derivative patent that holds attention in industrialization sectors, especially the needs of process development of their product. Patent portfolio describes how successful a company is expanding its business in general by showing revenue coming out from legal activities and also their journey achieving their goals.

IP class generates the most patent and derivative, used in industrial application which is shown in G06F17/00. It comprises digital computing or data processing equipment or methods specially adapted for specific functions (information retrieval, database structures, or file system structures, therefor G06F16/00), which are very dominant.

Further recommendation from this paper is that it is necessary to use patent tools to see the foresight of the existing technology in industry. So, it can evaluate the expansion of product development needed in the market.

\section{ACKNOWLEDGMENT}

The author would like to thank the Research Center for Science, Technology and Innovation Policy and Management, Indonesian Institute of Sciences for support and funding in applying this paper into a journal.

\section{REFERENCES}

Andersen P.D., Andersen A.D., Jensen P.A., Rasmussen B. (2014). Sectoral Innovation System Foresight in Practice: Nordic Facilities Management Foresight. Futures, vol. 61, pp. 33-44.

Balbi, E. (2001). Prospectiva, una Herramienta de Acción. Revista científica de UCES, 5(1), 1218. Retrived from: http://dspace.uces.edu.ar:8180/dspace/bitstream/ ha-

dle/123456789/360/Prospectiva_una herramient a de acci\%F3n.pdf? sequence $=1$.

Bernstein, P. A. (1998). Repositories and ObjectOriented Databases [Electronic version]. SIGMOD Rec. Vol. 27, Issue 1, Mar. 1998), 88-96.

Cassandra, M.S.; Dalibor Sacha, E.M. (2015). Do stronger intellectual property rights increase inno-vation? Word Dev. 66, 665-677.

Ernst, H. (1997). The Use of Patent Data for Technological Forecasting: The Diffusion of CNC Technology in The Machine Tool Industry. Small Business Economic. 9: 361-81.

Ferianto, Hendrix T., (2014). The Opportunity for Research and Development of New and Renewable Energy in Indonesia Through Patent Information, Proceeding of The $7^{\text {th }}$ Indonesia International Conference on Innovation, Entrepreneurship, and Small Business, 721-730.

Gallouj F., Weber K.M., Stare M., Rubalcaba L. (2015). The Futures of the Service Economy in Europe: 
Jurnal Bisnis dan Manajemen, Volume 20, No. 2, September 2019, p. 175-193

A Foresight Analysis. Technological Forecasting and Social Change, vol. 94, pp. 80-96.

Gantz BJ, Reinsel D., (2011). Extracting Value from Chaos State of the Universe: An Executive Summary. IDC iView. 1-12.

Gao, L., Porter, A.L., Wang, J., Fang, S., Zhang, X., Ma, T., Wang, W., Huang, L. (2013). Technology Life Cycle Analysis Method Based on Patent Documents. Technol. Forecast. Soc. Chang. 80 (3), 398-407.

Georghiou L., Cassingena Harper J. (2013) Rising to the Challenges - Reflections on Future-Oriented Technology Analysis. Technological Forecasting and Social Change, vol. 80, no 3, pp. 467-470.

Georghiou L., Harper C.J. (2011). From Priority Setting to Articulation of Demand: Foresight for Research and Innovation Policy and Strategy. Futures, 43 (3): 243-251.

Grupp H., Linstone H.A. (1999) Around the Globe Resurrection and New Paradigms. Foresight, vol. 94, pp. 85-94.

Harvey C. 2018. The Big Data Market is Booming, With Much of the Enterprise Spending Going to Cloud-Based Solutions. https://www.datamation.com/big-data/big-datamarket-2018-growing-and-moving-to-thecloud.html. Access on July 9, 2019.

Hendrix T. (2014). Implementation Policy of Acquisition Intangible Assets in Government Financial Statement, Proceeding The 6th IICIES, PP. 89-94.

Hidalgo-Nuchera, A., Iglesias-Pradas, S., \& Hernández-García, A. (2009). Utilización De Las Bases De Datos De Patentes Como Instrumento De Vigilancia Tecnológica. Profesional De La Informacion, $\quad 18(5)$,

doi:10.3145/epi.2009.sep.04.

Hsieh, C. (2013). Patent Value Assessment and ComMercialization Strategy. Technological Forecasting and Social Change, 80(2), 307319. doi:10.1016/j.techfore.2012.09.01.

Huang L., Zhang Y., Guo Y., Zhu D., Porter A.L. (2014) Four-Dimensional Science and Technology Planning: A New Approach Based on Bibliometrics and Technology Roadmapping. Technological Forecasting and Social Change, vol. 81, no 1, pp. 39-48.
Huang T, Lan L, Fang X, An P, Min J, Wang F. (2015). Promises and Challenges of Big Data Computing in Health Sciences. Big Data Res. 2(1): 2 - 11.

James M, Michael C, Brad B, Jacques B, Richard D, Charles R. (2011). Big Data: The Next Frontier for Innovation, Competition, and Productivity. McKinsey Glob Inst.

Keenan M., Popper R. (2008) Comparing foresight 'Style' In Six World Regions. Foresight, vol. 10, no 6, pp. 16-38.

Laney D. (2001). 3D Data Management: Controlling Data Volume, Velocity and Variety. Application Delivery Strategies.

Lee, J. (2015). Industrial Big Data. China: Mechanical Industry Press.

Lee, Il Won. (2015). Technology Foresight and Its Implementation Strategy. International Journal of Innovation, Management and Technology, Vol. 6, No. 6, 383-386.

Lin, H., Chan, T., \& Ien, C. (2013). Mapping of Future Technology Themes in Sustainable Energy. Foresight, $\quad$ 15(1), 54-73. DOI:10.1108/14636681311310141.

Manyika, J., Chui M., Brown B., Bughin J., Dobbs R., Roxburgh C., Byers A.H. (2012). Big data: The Next Frontier for Innovation, Competition, and Productivity. McKinsey Global Institute.

OECD (Organization for Economic Co-operation and Development). Compendium of OECD Work on Intellectual Property Rights (IP). 2007. Available online:http://www.oecd.org/sti/inno/34305040.pdf (accessed on 28 June 2019).

Philip Chen C.L, Zhang C.Y. (2014). Data-intensive Applications, Challenges, Techniques and Technologies: A Survey on Big Data. Inf Sci. 275: 314-347.

Popper, R. (2008 b). How Are Foresight Methods Selected? Foresight, 10(6), 62-89.

Rockhoff, K. (1991). Competitor Technology Intelligence in German Companies. Industrial Market Management. 20: 91- 8.

Rodríguez, M. \& Tello, M. (2012). Applying Patent Analysis with Competitive Technical Intelligence: the Case of Plastics. Journal of Intelligence Studies in Business, 2, 51-58.

Rohrbeck, R., Schwarz, J. (2013). The Value Contribution of Strategic Foresight: Insights from an 
Jurnal Bisnis dan Manajemen, Volume 20, No. 2, September 2019, p. 175-193

Empirical Study of Large European Companies.

Technological Forecasting \& Social Change.

Vecchiato, R. (2012). Strategic Foresight and Environmental Uncertainty: A Research Agenda. Foresight, 14(5), 387-400.

Wu X, Zhu X, Wu G-Q, Ding W, (2014). Data mining with big data. IEEE Trans Knowl Data Eng. 26(1): 97-107.

Yanhong L., Runhua T. (2007). Text Mining Based Patent Analysis in Product Innovative Process, Boston: Springer Verlag. 